ing based by and large upon a doctoral thesis into which much archival research went. South Africa's Flying Cheetahs is recommended to those potential readers who do not have ready access to the original thesis.

Major I.J. van der Waag, Documentation Service, Private Bag X289, Pretoria 0001.

\section{PYRAMIDS AND POPPIES The 1st SA Infantry Brigade in Libya, France and Flanders 1915-1919}

\author{
Peter K.A. Digby \\ 1993 \\ Ashanti Publishing, Rivonia \\ 444 pages \\ Illustrated \\ R90 \\ ISBN 1874800537
}

Pyramids and Poppies by Peter Digby is a book entirely devoted to the fortunes, and misfortunes, of the 1st South African Brigade during World War One. The Brigade was the first South African force ever to experience combat in Europe or North Africa. As this grants the contingent a distinctive standing in local military history, Pyramids and Poppies is a book which will be of interest, not only to World War One enthusiasts, but to most of warfare's other ardent fans as well.

Pyramids and Poppies commences with the formation of the 1st SA Brigade at Potchefstroom in 1915 and details the training and equipping of the Brigade in South Africa. The book then follows the Brigade through its early adventures in England and North Africa during 1915/1916. The Brigade was dispatched to Africa in order to lend assistance in the Sanussi campaign, which proved to be the ideal opportunity for the men to hone their combat skills. Suffering very few casualties, it was a time of excitement and new experiences for the Brigade's young soldiers. In addition, there were visits to Egypt's spectacular ancient monuments and the seedy delights of Cairo and Alexandria, to provide welcome breaks from army life.

However, by April 1916 the 1st SA Brigade was once more on its way to Eu- rope. On arrival in France the South Africans at once departed for the Western Front. Here they fought and died in the great battles of Delville Wood. Marrières Wood, Warlencourt and Fampoux, to name but a few. The writer relates this time of tragedy, describing the constant stream of new faces as fresh drafts arrived to replace the dead and wounded. An effective picture of the hopelessness often felt is successfully conveyed. This is rather important as no other South African Brigade has ever suffered such high casualties. Thousands of young South Africans were lost in the mud of France and Flanders. More often due to the absolutely shocking and reckless tactics of the British generals rather than the superiority of the enemy. The writer weaves through this tale of misery and manages to prevent the sheer mass of facts and the tediousness of the war's cycle of trenches and death in detracting from the book's appeal.

Naturally Pyramids and Poppies is not without some flaws. In places the factual content is questionable. One inaccuracy appears on the front cover, which unfortunately means that it is very noticeable. The offending word is "Libya", where the term "Cyrenaica" would have been more appropriate, since at the time of the First World War, Libya did not exist. Secondly the inclusion of the flattering correspondence between the writer and Dr Farquharson (who wrote the book's foreword) was unnecessary. The same can be said of the writer's references to King Edward VII school. As it is stated on the book's dust cover that the author is a product of the above establishment the whole effect was rather transparent and would have been better left well alone. Source referencing could have received a little more attention. This is particularly true with regard to archival material. The referencing of primary sources refers to whole archive groups which is too generalised. It should also be pointed out that more use could have been made of these sources.

One area in which the writer has a definite weakness is that he favours the kilted regiment of the lst SA Brigade, namely 4 SAI, over the formation's other three infantry units. This is per- 
haps the book's greatest failing as it cannot, be termed a balanced account of the South African experience on the Western front. One concedes the point that due to their unusual attire, the 4 SAl were perhaps the most glamorous of the South African regiments. However, this does not serve to excuse the disregard for academic impartiality displayed by the writer, who should have practised more restraint.

Unfortunately Pyramids and Poppies takes on a rather emotional tone at times, specifically the appendices dealing with the question of World War One Battle Honours. A complicated process at best, the writer has oversimplified the matter by attempting to draw a comparison between South Africa and other Commonwealth countries. However, correlations in this respect do not exist, this is exacerbated by the fact that quite a substantial amount of the "evidence" offered in support of this case was wrong. The impression one gets after reading this appendix is that the writer has an axe to grind.

These shortcomings should not detract from the fact that Pyramids and Poppies is a well written book. An attractive dust cover and marvellous photographs serve to enhance the text, which is generally of high standard. Digby skilfully prevents the gruesome developments of the war from becoming oppressive reading, and although dealing with a subject matter which is anything but funny, certain of the stories it contains are very comical. The book presents a less hysterical view of Delville Wood than one is accustomed to, which is refreshing. Efforts to highlight the importance of the other major battles fought by the Brigade are quite effective.

Pyramids and Poppies is certainly one of the better releases in the "South Africans at War" series and is a commendable tribute to the tormented but triumphant, 1st South African Infantry Brigade.

N.M. Cowling, Directorate Documentation Service, Private Bag X289, Pretoria 0001.

\section{NO REWARD BUT HONOUR? The British soldier in the 1990s}

\author{
John Baynes \\ Brassey's (UK), London 1991 \\ 215 pages \\ Retail Price unavailable \\ ISBN 0080403662
}

Luitenant-kolonel Sir John Baynes was 2IB van die lste Battaljon van die Cameronians (Scottish Rifles) ten tye van die ontbinding daarvan. Hy was daarna verbonde aan die Queen's Own Highlanders (Seaforth en Camerons), die Universiteit van Edinburgh en 1ste Battaljon 52 Lowland Volunteers. Nadat hy in 1972 afgetree het, was hy een van die eienaars van ' $n$ hotel in Wallis. Deesdae wy hy hom aan skryfwerk en is tans besig met ' $n$ biografie oor die lewe van generaalmajoor R E Urquart.

Die outeur se ander werke sluit oa in:

The Jacobite Rising of 1715

Morale: a study of men and courage

The history of the Cameronians (Scottish Rifles)

Soldiers of Scotland (in samewerking met John Laffin)

Ten tye van sy verbondenheid aan die Universiteit van Edinburgh het hy die voorloper tot No reward but honour? $\mathrm{nl}$ The soldier in modern society voltooi.

Die outeur het ' $n$ intensiewe studie van die onderwerp gemaak en 'n omvattende verslag daaroor weergegee, soos blyk uit die inhoudsopgawe van die boek. In die Inleiding spreek hy die hoop uit dat hierdie boek ook deur persone buite die militêre milieu gelees sal word. aangesien die studie van verdediging deur alle regdenkende burgers belangrik geag behoort te word. Die boek is deurspek met toepaslike en baie interessante aanhalings, soos die volgende oor die oogmerke van diegene wat 'n studie van oorlog maak:

"First in the hope of preventing it; secondly, if it none the less occurs, in the hope of surviving it; and thirdly, for the purpose of understanding the society in which we live, which whether we like it or not is influenced by past wars and the militant spark in mankind" Dr Noble Frankland. 